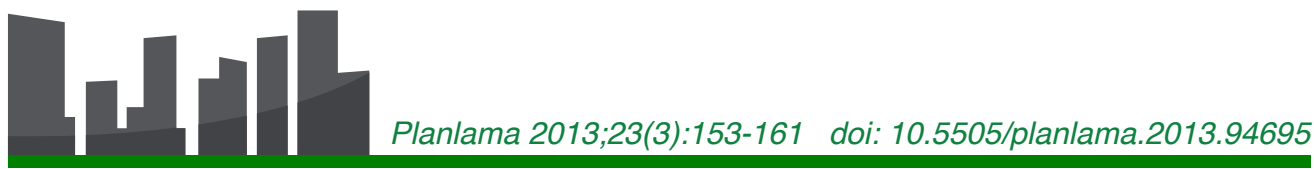

\title{
Implications of Socio-spatial Segregation in Urban Theories
}

\author{
Kentsel Kuramlarda Sosyo-Mekansal \\ Ayrışmaya Dair Çıkarımlar
}

\author{
Gizem Caner, Fulin Bölen
}

Istanbul Technical University, Urban and Regional Planning Department, Istanbul

\begin{abstract}
Since the beginning of the twentieth century, our understanding of cities has gone through important changes due to major sociospatial processes. Specifically, over the last few decades processes like globalisation and decolonisation have produced significant consequences in cities and these have attracted the attention of prominent urban scholars. Of these consequences, segregation has become infamous in the discourse of numerous disciplines, including governmental debates and policies. However, sociospatial transformations have been a source of new challenges for urban theory makers throughout history. At a certain point, the physical focus of early urban theories was no longer sufficient to interpret the city, causing a shift towards process-oriented theory-making. The central theme of this paper is to investigate this shift by analysing the evolution of urban theories with regard to their implications for urban social geography. In this context, the analytical focuses of main urban theories are evaluated and their explanatory power for socio-spatial segregation is stressed. Such a developmental perspective enables us to observe urban theories' receptiveness to changing circumstances, as well as their power to guide urban scholars. The evaluation reveals that urban theories capture the spirit of their time (zeitgeist) through their own lenses and explain the social geography of the city either partially or fully with regard to these lenses. In conclusion, it may be said that urban theories which have implications for segregation are not generated universally, but rather in specific frameworks which might or might not be explanatory for other circumstances. All in all, it is believed that this evaluation will provide guidance for future studies that aim to understand and/ or develop the role of urban theories in explaining socio-spatial segregation in the city.
\end{abstract}

Key words: Segregation; socio-spatial segregation; urban social geography; urban theories.

\section{ÖZ}

Yirminci yüzyıl başlarından beri, kentler hakkındaki anlayışımız, büyük ölçekli sosyo-mekansal süreçler nedeniyle önemli değişimler geçirmiştir. Özellikle 1950'lerden bu yana, küreselleşme ve sömürgecilik sonrası süreçler, kentsel araştırmacıların dikkatini çeken olumsuz kentsel sonuçlar doğurmuşlardır. Bu sonuçlar arasında, ayrışmanın kötü bir ün saldığı ve yönetim birimlerinin söylem ve politikalarında yer edindiği görülmektedir. Ancak, bu sosyo-mekansal dönüşümler, kentsel kuramcılar için uzun zamandır yeni mücadele alanları ortaya çıkarmaktadır. Belirli bir noktaya gelindiğinde, önceki kentsel kuramların fiziksel yaklaşımları kenti yorumlamak için yetersiz kalmış ve bu da, süreç odaklı kuram geliştirmeye doğru bir kaymanın yaşanmasına neden olmuştur. Bu makalenin ana konusu; bu yaşanan dönüşümü incelemek için, kentsel kuramların evrimini, kentsel sosyal coğrafyaya ilişkin çıkarımları bağlamında analiz etmektir. Bu çerçevede, temel kentsel kuramların analitik odak noktaları değerlendirilerek, sosyo-mekansal ayrışmayı açıklama konusundaki yeterlilikleri üzerinde durulmaktadır. Gelişimsel bakış açısı, kentsel kuramların değişen durumlar karşısındaki esnekliğinin gözlemlenmesini sağlamaktadır. Ayrıca, kentsel araştırmacılara rehberlik etme konusunda ne kadar etkili olduklarını ortaya koymaktadır. Değerlendirme sonucunda, kentsel kuramların, ortaya çıktıkları dönemin özünü, kendi kuramsal çerçevelerinde yansıttıkları ve kentin sosyal coğrafyasını, bütüncül ya da parçacıl olarak, bu çerçeveye göre değerlendirdikleri görülmüştür. Sonuç olarak, ayrışma için çıkarımlarda bulunan bu kentsel kuramların evrensel olarak geliştirilmedikleri, dolayısıyla, başka durumlar için her zaman açıklayıcı nitelikte olamayacakları söylenebilir. Bu değerlendirmenin, kentsel kuramların sosyo-mekansal ayrışmayı anlama ve/veya geliştirmeyi amaçlayan ileriki çalışmalara rehberlik etmesi beklenmektedir.

Anahtar sözcükler: Ayrışma; sosyo-mekansal ayrışma; kentsel sosyal coğrafya; kentsel kuramlar. 


\section{INTRODUCTION}

Urban theorists try to make sense of events that lead to growth and change in the urban framework. For the last few decades, these events are mostly accredited to be major socio-spatial processes like globalisation, post-colonialism, improvements in communication technology and their concurrent process of mass immigration. In turn, these processes produced undesired transformations on the urban ground. Accordingly, divisions of capitalist production processes, urban segregation and increasing inequality between the affluent and deprived city districts became common themes studied by urban scholars dealing with the cities of the developed western world (Safier, 1997).

In our contemporary world, segregation became one of the most infamous concepts postulated in numerous disciplines, including governmental debates and policies. However, segregation in cities is not a new phenomenon. It has existed since prehistoric times. Ancient prototypes for the segregated city were visible in the village of Kahun, Egypt as early as 2670 BC and in the village of Amarna near Cairo I 300 years later (Marcuse, 2002; Calame and Charlesworth, 2009). Beginning with the Han Dynasty in 206 BC, Chinese cities became probably the earliest fully walled cities that not only served for protection, but also for classifying and controlling 'townsfolk' (Marcuse, 2002). Colonial past of segregation, on the other hand, dates back to Middle Ages when the English Colonists started to settle in Ireland. Similar practices were visible in the ghettoes of Venice and other European cities established for Jews.

The word 'segregation' was first coined for techniques to racially isolate Hong Kong and Bombay in the 1890s and from then on spread worldwide (Nightingale, 2012). New urban planning techniques aimed at separating zones according to racial differences got to its peak point in 1948, with 'apartheid' in South African cities. The entrance of racial dynamics into the real estate market, specifically in American cities like Chicago, rendered urban divisions more durable. These developments left legacies in the contemporary world. Today, segregation and division became a phenomenon in cities all over the world, and cities have become sharply divided by class, race, ethnicity and the like.

Even though segregation has a long history, what makes it pronounced in our contemporary period is the increasing intensity of the socio-spatial processes mentioned above. This paper is concerned with socio-spatial segregation which can be defined as a state of socio-spatial exclusion and isolation among social groups (Boal, 1987; Peach, 1996a, 1996b). The ever-growing segregation literature defines numerous types of segregation, such as; residential, ethnic, racial, religious etc. Social segregation includes racial, religious, class and ethnic segregations which occur in the city space. Spatial segregation on the other hand, can be seen as the residential separation of groups within a broader population (van Kempen and
Özüekren, 1998). The dialectic combination of the two types represents their mutual relationship.

As the city changes, the ways we think and interpret cities modify substantially. In other words, the transformation of social geography in cities produces new challenges for urban theory makers. Therefore, firstly, this paper presents the changing nature of urban theory making. In the second part, main urban theories are evaluated according to their explanatory power for socio-spatial segregation with regards to their analytical focus points. This section traces whether the history of segregation, explained above, has been reflected in the history of urban theories. As a conclusion, a table is drawn to comprehensively observe the implications for segregation of each urban theory that has been analysed. All in all, it is believed that this evaluation will be illuminative for future studies that aim to understand and/or develop the role of urban theories in explaining socio-spatial segregation in the city.

\section{EVOLUTION OF URBAN THEORY MAKING}

Before moving on, it is important to differentiate planning theories from urban theories in order to eliminate misconceptions. According to Fainstein (2007), this distinction is not intellectually viable due to I| the historical roots and justification for planning; 2| the dependence of effective planning on its context; and 3 | the objective of planning to create a just city. These reasons have caused planning theory to remain limited compared to urban theory making. Given these circumstances, this paper solely deals with urban theories, however, does not underestimate or ignore the importance of planning theories.

The mentality of urban theorists adapts to the world conjuncture that surrounds them. Accordingly, the way they understand and interpret the city alters in line with their changing environment. According to Batty (2007), these alterations have taken the following paths:

Cities as artefacts to be designed $\rightarrow$ Systems that evolve, change and grow.

Emphasis on structure and form $\rightarrow$ Emphasis on behaviour and process.

Physicalism which dominated city planning $\rightarrow$ Concern for social processes.

In a similar vein, Harris (196I) identifies three main streams of thought in urban theory building. The first stream is design oriented. Urban form is treated as a subject to control and direct for a variety of purposes (defence, health, aesthetics etc.). Historically, design orientation has had a limited but powerful influence which can be mainly expressed through a few master-planners and architects, such as, Doxiadis and Vitrivius (Batty and Longley, 1994). With technological advances and growth of a pluralistic society, this tradition of thought mainly faded, giving way to the second stream. This stream was concentrated on describing the urban form, fol- 
lowing naturalistic views of nineteenth century economics, sociology and biology. At this time, economic theory about the influence of space on location was developing very slowly, rendering descriptive theories very simplistic. Harris (196I) indicates that three major current descriptive models of urban form derived from these simple ideas. First one is the theory of Von Thünen, 1826, where concentric zones of different uses of land tend to form an urban market/centre (McLoughlin, 1969). This was taken one step further by Burgess' concentric zone hypothesis of the location of residential areas by type (Anderson and Egeland, 196I). The second descriptive theory is Hoyt's sectoral theory from sociological concepts of segregation (Berry, 1964). And the last theory is concerned with Harris and Ullman's (1945) notions of multiple nucleation of the city.

All these descriptive theories are largely deterministic, as their name suggests. Their classical structure indicates equilibrium, with simple, discontinuous and even rejected change. They can only assess the probabilities due to continuum of trends. The processes that give rise to change are left out of question. Therefore, one of the main consequences of this type of theory building was the need to focus on the process. Harris (196I) indicates that the orientation of research in the direction of examination of processes is a natural outgrowth of this second main stream.

Roger's (1967) perspective on the change of thought (from description to process) is akin to Harris's (1961) one. He articulates that this change has gone through two main streams: system- and process-oriented urban thinking. The first point of view is macro scaled, focusing on the phenomena of urban growth and change and on the regulative forces acting to promote orderly development. It focuses on a particular site and is concerned with the determinants of activity. The problem is viewed mechanically, with the principal factors of demand, supply, income and capital, where the behaviour of land market and rent are the main concerns. Systems-oriented approach presented by Rogers, coincides with Harris's descriptive theories. The second main stream approaches to the subject via factors that give rise to the phenomena of change. Instead of focusing on a location, the behaviour of decision units are analysed which seek for the appropriate location for an activity. Indeed, the general emphasis on process started to reveal itself in urban thinking during 1960s. Webber et al. (1964), for example, articulate a common emphasis on the need to understand processes, the ways which change arises and generates further response.

Process-oriented approach gives rise to the third stream of Harris's urban theory classification; explanation of urban form. According to Harris, this thought of action requires a multi-dimensional perspective that can produce a general urban theory, sheltering all aspects of the city.

The following section will give a brief account of main urban theories within this framework in order to evaluate how socio-spatial segregation has been manifested in their focal points.

\section{URBAN THEORIES AND SOCIO-SPATIAL SEGREGATION}

In this section, main urban theories-which have significant presence in the shift of emphasis from 'structure', 'form', and 'physicalism' to 'process', 'behaviour', and 'change-will be evaluated with regards to segregation. Since segregation has been a norm in the historical development of cities, we will be able to discern when, and in which conjunctures, it has gained importance for urban theory makers.

\section{Design-Oriented Approaches}

Industrial revolution and ensuing processes like urban population increase caused infrastructural, housing, and environmental problems in cities. Unpleasant conditions made urban thinkers theorise about ideal cities and how these cities can be achieved. As a result, starting from the late 19th century, "more abstract conceptions of the ideal city system based on social and economic ideas of utopia became important" (Batty and Longley, 1994). Two significant examples are drawn from these approaches to evaluate their perception on segregation.

Olmsted's City Beautiful of 1893 is one of the first movements which tackled with the devastating conditions of cities. The aim was to 'beautify' the city by urban design practices, and by doing so, create cohesion between urban dwellers with the usage of public spaces (Ersoy, 2007). It was pre-assumed that the poor would be more trustworthy and committed due to these new developments, and that the better-off part of the population living in the suburbia would return to the new and beautified city centres.

Howard's Garden City movement of 1898 is different from Olmsted's approach, in that it is focused on moving away from the city, rather than restructuring public spaces in the city. It is designed to incorporate elements of country, alongside city life. Howard's notion that working class deserved better and more affordable housing could not be obtained in his first Garden City, Letchworth, where housing prices could not remain attainable for blue-collar workers, making the town population mainly composed of middle-class workers (Ersoy, 2007).

Olmsted's emphasis on public spaces to create cohesion and Howard's intention to provide affordable housing for the working class are social considerations which display that these urban thinkers are concerned with socio-spatial divisions within the society.

\section{Neo-Classical Approaches}

In the nineteenth century urban hierarchies were being redefined due to economic developments, industrialisation and 
urban growth. These developments caused economic geographers to focus on industrial location and competition among places. The neoclassical location theory, developed by Von Thünen in 1826, where concentric zones of different uses of land tend to form an urban market/centre (McLoughlin, 1969), was mainly about the competitive operation of the land market (Gaffikin and Morrissey, 20I I).

Taking this theory of economic geography one step further is Christaller's central place theory of 1933. Christaller demonstrated how, under certain conditions, a hierarchy of places would surface in a hexagonal pattern shaped by market areas. Apparent in its name, central place theory is associated with the terms 'core' and 'periphery'; where competition to provide high-order services produces central cities as well as unserved small towns.

It can be observed that these neoclassical approaches were mainly descriptive rather than explanatory (Gaffikin and Morrissey, 20II). Even though central place theory attracted a lot of attention, in time it became clear that the variations of historical and geographical contexts were ignored (Wyly, 20l0). Furthermore, they were criticised for only dealing with firms; disregarding the role of other agents such as individuals or regional and international economies (Wyly, 2010; Gaffikin and Morrissey, 201 I).

\section{Chicago School}

The works of Chicago School are famous for transforming planning from a design profession to a social science (Fainstein, 2007). It resembles the first stream of urban thought that explicitly deals with socio-spatial segregation.

By the twentieth century with the advent of the 'industrial city', Park (1915, 1936) and the Chicago School of Urban Sociology produced enormously influential theoretical and empirical work on cities. Theorists of this school used a biological metaphor-a social organism-to produce a scientific view of the city. Three traditional approaches splintered from the works of this school; the human ecology approach, social areas analysis and factorial ecology. They shelter significant insights for explaining segregation, a phenomenon which was obviously on the rise.

\section{- Human Ecology}

Human ecologists can be seen as the first group of researchers who systematically paid attention to the description of patterns of spatial segregation (van Kempen and Murie, 2009). The term ecology is used to represent the relationship between social attributes and spatial patterns. The most distinctive feature of the approach was its emphasis on the city as a 'social organism', with individual behaviour and social organisation governed by a 'struggle for existence' (Knox and Pinch, 2010). As it was conceived at a time when Darwinism was strong, the urban space was seen as where the fittest social groups could survive best in struggle for best settlement (Park, 1936).

Main concepts of this approach are as follows; (I) 'competition' between various population groups in the city; (2) 'dominance' of a particular group or certain functional areas; (3) 'natural areas' which are the results of social and ecological processes; (4) 'invasion' of a natural area by a competing group; and (5) the ultimate 'succession' of a competing group in a natural area (Park, 1936).

The spatial model of the human ecology approach was first introduced by Burgess during the 1920s, and then altered by Hoyt in 1930s and later by Harris and Ullman in 1940s (Figure I).

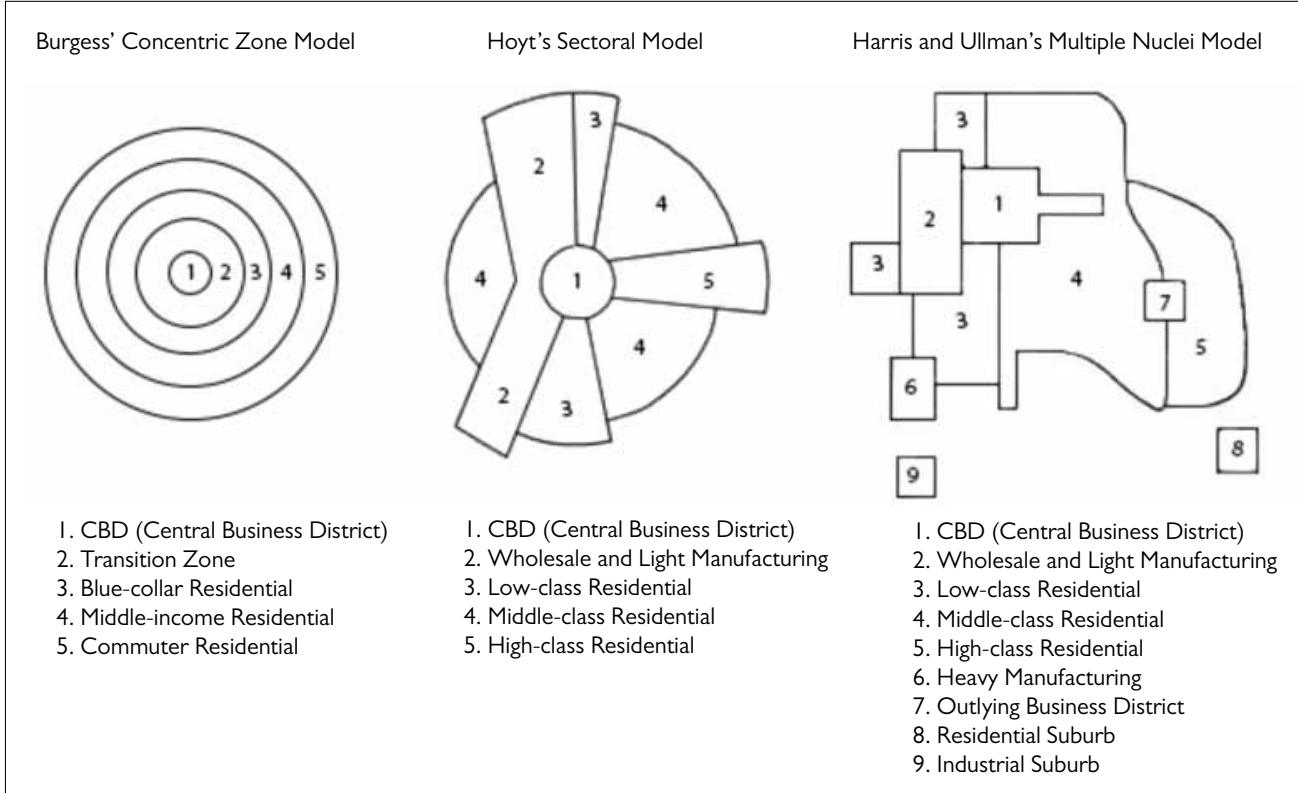

Figure 1. Spatial Models of Human Ecology Approach (redrawn from Harris and Ullman, 1945). 
Burgess' concentric zone hypothesis emphasised the importance of growth from the centre by suggesting four zones moving out concentrically from Zone I, the central business district. These zones were classified according to types of residential areas; in terms of density of the dwelling units and socio-economic status of the residents (Anderson and Egeland, 196I). The main argument of this hypothesis is that new coming immigrants first concentrate in the less-expensive zone (Zone 2: transitional zone), and once they have upgraded their economic status, move outwards to higher-status residential zones. The underlying process was characterized by invasion and succession, where one group invades and succeeds the other as it moves upwards on the economic, and outwards on the spatial scales (Murdie and Ghosh, 20l0). Here, assimilation was acknowledged as the only possible outcome (Peach, 2005) and the final pattern of segregation was seen as a 'natural equilibrium' or 'biotic balance'.

Another representative of the Chicago School is Hoyt with his sectoral approach. Here, the city is divided into sectors (in an axial pattern mainly along transport routes), within which a concentric pattern may or may not be found (Anderson and Egeland, 196I). These sectors (residential areas) are determined by average rental value of a dwelling unit. In this way, Hoyt modifies the CBD-centred position of Burgess' hypothesis.

The next most popular alternative view was developed by Harris and Ullman (1945) and is known as multiple nuclei. This is usually regarded as a metropolitan phenomenon rather than urban (Berry and Rees, 1969). The idea of a unitary city form is abandoned, and instead it is argued that multiple employment centres form the nuclei of multiple residential patterns (van Kempen, 2007).

In spite of creating everlasting effects on the way we interpret cities-specifically in terms of socio-spatial processes-human ecologists have been criticised for many reasons. The most important one was put forward by Wirth (1945), another theorist from the Chicago School, who stressed that social and cultural dimensions were more significant than the creation of biological analogies and models. Another criticism is that they excessively rely on competition as the basis of social organisation, where individuals make their locational decisions on the basis of economic rationality (Timms, 1978).

\section{- Social Area Analysis}

The human ecology approach was followed by an empirical approach proposed by Shevky and Bell in 1955 to investigate Los Angeles and San Francisco. They used deductive analysis methods to relate what is happening within the city to the more general changes taking place within the encompassing society (Timms, 1978). They constructed three different indexes to allow comparison of social areas (urban neighbourhoods) within different cities: 'social rank', 'urbanization', and 'segregation' (Do, 1988). Each index included one to three census variables in order to classify social areas based on their scores (Berry and Rees, 1969).

In their conclusion for spatial aspects of social area analysis, Anderson and Egeland (196I) state that social rank varies sectorially, urbanisation concentrically, and segregation on the basis of concentration of certain minority groups-clusters-in limited neighbourhoods of the city. The importance of social area analysis regarding segregation is that it gives important insights on how social aspects are independently influential on spatial location: "Shevky and Bell turned the focus of study from zones and sectors in the city to nuclei or population clusters within the city" (Driedger, 2003).

\section{- Factorial Ecology}

Factorial ecology is an outgrowth of social area analysis. The difference mainly lies in two facts: that factorial ecology is an inductive method, and that it can comprise a wider set of variables. Factorial ecology has been used to analyse relationships between different groups of variables (social, economic, demographic and housing characteristics) with the objective of establishing common patterns (Knox and Pinch, 2010). The relationships between variables and spatial patterns are called factorial ecology (Rees, 1969).

Findings of factorial ecology studies-mainly conducted in American cities-have coincided with Shevky and Bell's dimensions: 'socio-economic status', 'family status', and 'ethnic status'. When these three social dimensions are superimposed on the physical space of the city, they form a lattice of sectors, zones, and segregated areas of 'communities' with similar social, family and ethnic statuses (Berry and Rees, 1969; Know and Pinch, 2010).

Factorial ecology became insufficient with time since it did not account for economic, technological, demographic and social change, such as, the emergence of 'migrant status' (Timms, 1978) and the increasing complexity of ethnic differentiation (Knox and Pinch, 2010).

\section{Behavioural Approaches}

Despite Chicago School's attempts to induce social aspects into planning profession, critiques developed within the social movements of 1960s and 1970s (Fainstein, 2007). Jane Jacobs' ground-breaking book, 'The Death and Life of Great American Cities' published in 1963 was the first attempt to propose new planning strategies instead of offering sole critique (Jacobs, 1996). Similar proposals came from Paul Davidoff's advocacy planning in 1965, and Norman Krumholz's equity planning in 1982.

Starting from 1970s, an emphasis on relationships between the urban and individual behaviour surfaced. This approach was mainly inductive; it aimed to develop generalized spatial patterns based on investigations at the micro-level (Gaffikin and Morrissey, 20II). Explanations included preferences, perceptions, and decision-making processes of the individual in 
residential mobility, hence encompassing the demand side of the housing market.

Peach (199I) refers to this approach as 'choice school', where choices of households are linked to family life cycles (e.g. marital status, family size), income, life-style preferences, and employment location (Berry and Rees, 1969). Characteristics of the dwelling-e.g. floor space, number of rooms, type or ownership, price-also affect choice (van Kempen and Murie, 2009). Since different kinds of dwellings are located in different parts of the city, the eventual pattern is segregation of different types of households.

The bottom-up approach inherent in the works of this school was developed in several veins. One of these, the ethnic-cultural approach, attributes differences among housing conditions and residential patterns to cultural and ethnic differences between groups. The fact that differences within groups are as important as differences between groups is the most promising part of this approach.

\section{Deterministic Approaches}

Investigators of the relationship between space and behaviour may fall into deterministic perspectives while separating 'cause' and 'effect'. In other words, distinguishing whether people's behaviour patterns are responsible for their urban condition or a response to it can provoke either cultural or environmental determinism.

\section{- Cultural Determinism}

By the 1960s, particular sociologists were convinced that it was 'social' rather than 'geographical' location which really mattered (Gaffikin and Morrissey, 20II). The emphasis of most research in behavioural approaches has been in the way of thinking that urban settings influence individual and group behaviour, and hence, 'deviant' behaviour is caused by depraved urban settings (Knox and Pinch, 2010).

Wirth's popular classic essay, 'Urbanism as a way of life', published in 1969, carries deterministic overtones relevant to individual and group behaviour (Knox and Pinch, 20l0). According to him, the culture of urbanisation caused cities to strive for accommodating large numbers of people from a mixed social background and this eventually led to social disorder and dispute (Gaffikin and Morrissey, 20II). In the Wirthian theory, the attachment to 'space' as a cause contributes to cultural determinism.

\section{- Environmental Determinism}

Environmental determinism is the contrast idea of cultural determinism. In 1960s, cultural theories were introduced to explain urban deprivation. According to these theories, it was environmental, climatic and geographical factors which were responsible for cultures and individual decisions. Designation of 'culture' as a cause produced theories of environmental determinism. This meant that "where people lived greatly influences how they lived" (Gaffikin and Morrissey, 20II).

A narrower perspective of environmental determinism is architectural determinism where it is believed that the built environment is the only determinant of social behaviour. Its roots can be traced from Bentham's Panopticon (Foucault, 1995) to design oriented approaches like Le Corbusier's radiant city until recent times.

Crime Prevention through Environmental Design (CPTED) was developed in 1970s in this strand. It attempts to deter criminal behaviour through environmental design. Oscar Newman's (1996) views on 'Creating Defensible Space' are in this vein. Brand (2009a; 2009b) and Fregonese and Brand (2009) also apply this framework to investigate the impact of divisive urban artefacts-in Belfast-on the behaviour of the individuals. They conclude that physical interventions should not only be for prevention of crime, but should also encourage desirable behaviour.

According to Soja (1980), the 'socio-spatial dialectic' is ignored by proponents of both deterministic approaches. In her words: "the primary source of misunderstanding over the relationship between social and spatial structures may lie in the failure [...] to appreciate the essentially dialectical character of this relationship" (Soja, 1980).

\section{Managerialist Approaches}

The neo-Weberian managerialist approach grew out from the need of reformulating urban theory during a period of urban riots and economic crisis of the 1960s and 70s (Gaffikin and Morrissey, 20II). Its emphasis was on organisation of social space in terms of managerial roles.

While behavioural approaches focused on the demand/choice side, Neo-Weberian approaches were more interested in the 'constraints' side (Peach, 1991). This perspective was used in housing research to explain the segregation and concentration of certain households, with reference to constraints the households faced while choosing their places to live (van Kempen, 2007). Pahl suggested that the key to understand 'constraints' were to be found in the activities, policies and ideologies of the managers ('gatekeepers') of urban systems (Pahl, 1969, in Knox and Pinch, 2010).

In this body of research, institutional arrangements and key 'actors' in the housing market were studied in order to explain the outcome of competition between conflicting social groups (Knox and Pinch, 2010). This research revealed important explanations for segregation worth mentioning: (I) objectives of professional officers are not always in the name of 'public interest' which means that stereotyping may cause discrimination; (2) people are distinguished from one another by their strength in the housing market; (3) budget cuts of the state causes declining incomes, inducing concentration of 
low income groups into neighbourhoods where dwellings are still affordable.

The fact that 'managerial' decisions are themselves subject to constraints by wider economic and political structures of the society, and that these forces are beyond the control of the managers, render urban managers as significant actors but with limited importance in the context of socio-spatial dialectic (Knox and Pinch, 20I0).

\section{Neo-Marxist Approaches}

Pioneers of neo-Marxist approaches are Manueal Castells, Lefebvre (1996) and David Harvey (1999). Thinkers of this literature insist that: (a) the urban system is a part of the process of reproduction of labour through consumption; (b) urban services which are a subject of collective consumption are mainly suitable for politicisation; (c) this politicisation results in urban social movements and conflicts, and can only be understood as an integral part of fundamental capitalist crisis (Keleş, 2002).

According to Gaffikin and Morrissey (20II), two main schools separated from this approach; (I) the structuralists concentrated on the global character of capitalism; and (2) regulationists considered internal relations within the nationstate, and how economies regulated their capitalist development, including its spatial component. Structuralists are allied with Marxian theories. Marx argued that conflict between two classes-capital owners and workers-was the underlying

Table I. Evolution of urban theories and their relevance to socio-spatial segregation

Urban theory Implications for segregation/division

Design oriented

Neo-classical

Chicago school

Behavioural

Deterministic

Managerialist

Neo-Marxist

LA school
Designs cities to accommodate all social classes in a more balanced manner with the main area of concern being beautification and better living conditions.

Underestimates socio-spatial relations that are not determined by economic reasoning.

Divides the urban according to the hierarchical pattern of market places, where concentric zones form a central urban market.

Describes segregation as consisting of concentric zones, sectoral patterns, or multiple nuclei. Zones, sectors and nuclei houses different parts of the population.

The zone of transition (zone 2 ) is the immigrant receiving area; one group invades and succeeds the other by moving upwards on the economic, and outwards on the spatial scales.

Assimilation is seen as the only outcome; due to processes of invasion-succession, the dominance of a social group is inevitable.

Social areas in cities (urban neighbourhoods) are constructed according to three indices: social rank (socioeconomic status), urbanisation (family status), and segregation (ethnic status). These indices form a lattice of sectors, zones, and segregated population clusters (communities) when imposed on physical space.

Acknowledges segregation as at least partly a result of individual preferences, perceptions, decisions and 'choices'.

Since different kinds of dwellings are generally located in different parts of the city, segregation of different household types is the logical result.

Ethnic-cultural approach emphasizes that differences within groups were as important as differences among them.

Cultural determinists attribute space as the cause of deteriorating social solidarity; Environmental determinists designate culture as the cause for the conditions people live in.

Approaches like Crime Prevention Through Environmental Design and Defensible Space claim that physical interventions can prevent undesired behaviour.

The 'socio-spatial dialectic' is ignored by proponents of both approaches.

Is used to explain the 'constraints' that households face when choosing their place to live.

Main findings: (I) discriminatory/exclusionary policies may cause constraints on ethnic minorities; (2) people are distinguished from one another by their strength in the housing market; (3) budget cuts of the state causes declining incomes, producing concentration of low income groups in neighbourhoods where dwellings are still affordable.

Social class is the major social division; other divisions are not taken into account.

Acknowledges social polarisation in cities among different ethnicities and identities as well as new fragmented spaces of interethnic conflict.

The city is perceived as privatised and political space; fortified with gates, barriers and walls defining the enclaves of opposing groups. 
mechanism of the capitalist society. Neo-Marxists attempted to update Marx's ideas of 19th century industrial city, to the 20th century (Knox and Pinch, 2010).

In Neo-Marxist approaches, social class is the only class considered in this theory; ethnicity, religion, nationality, political affiliation and the like are ignored. More importantly, the factor of human agency, in other words, the process of choice-of people to distribute themselves within the same social class-is poorly evaluated (Knox and Pinch, 2010; van Kempen and Özüekren, 1998). Nevertheless, the fact that Marxist perspective has clarified the structural components of the observed inequalities (among people in general and different ethnic groups in particular) is very important.

\section{LA School}

During the 1980s, a group of scholars based in California, began to study Los Angeles as an emblematic city of the 'postmodern' era. Edward Soja (1995), Mike Davis (1990), and Michael Dear were the main professionals advocating this school. Their works are based on their nomination of the Chicago school as the classical modernist vision of the industrial city, and contrast it with the postmodern city of Los Angeles (Dear and Flusty, 1998).

According to Soja (1995) six main 'restructurings' are eminent in Los Angeles which composite a postmodern urban geography:

I. A shift from Fordist to Post-Fordist urbanization. Processes of deindustrialisation of the Fordist city, and the reconstructions of more flexible production and accumulation systems.

2. Globalization and the formation of a global system of world cities. It follows Sassen's (200I) 'transnational urban systems argument'. Demographic transformations accompanying this trend generate the 'cosmopolis'. Influx of foreign capital and globalisation of the local economy changes the class structure and the 'dual city' (Mallenkopf and Castells, 1991) metaphor emerges.

3. Fragmentation and decentralisation. The city is turned 'inside out' through decentralisation and fragmentation which reterritorialise urban processes and create 'edge cities'. Urbanisation of the suburbs, growth of small towns and the emergence of megacities challenge the concepts of Chicago school models (concentric development no longer holds true).

4. Social polarization. Divisions among multiple ethnicities and identities and the increasing income gap forms new landscapes of interethnic conflict and deprivation.

5. Formation of fortified cities. Urban developments with gates, barriers etc. create landscapes with unstable boundaries as well as enclaves and turfs of opposite groups.

6. Emerging systems of social control. Behavioural, cultural, and ideological restructuring; the growing power of cyberspace; and spaces turned into marketable commodities - 'the city as a theme park' (Dear and Flusty, 1998).
This school has mainly been criticised for the fact that they see the city of Los Angeles as representative of all future urban forms. The second main criticism is brought to attention by the postcolonial thinkers. According to Jacobs (1996), the social polarisation argument of the LA school is mainly concerned with the immigrants as actors in the new global economy. Third major criticism is that they allocate a little or no attention to the works of Neo-Marxist urban theorists like Harvey, Castells and Lefebvre (Knox and Pinch, 2010).

\section{EVALUATION AND CONCLUSION}

The main concern of this paper has been to investigate how urban theories interpret issues of socio-spatial segregation on the urban arena. Table I submits a comprehensive summary of conclusions retrieved from the evaluation of urban theories and their implications for segregation (Table I).

The analysis reveals that segregation has not been a direct topic for urban theorists until the works of Chicago School. However, it is possible to find traces of thought related to issues of segregation in earlier theories. Nonetheless, with the advance of social conceptualisations of the city, following urban theories, directly or indirectly, have produced thoughts which had effects on understanding socio-spatial segregation.

The evaluation reveals that urban theories capture the essence of their time (zeitgeist) through their own lenses and explain the social geography of the city either partially or fully with regards to these lenses. The shift from design-oriented approaches to process-oriented ones has been a consequence of major socio-spatial processes which transformed the city. Segregation, being one of the main problems produced as a result of these processes became an entrenched part of urban theories thereafter, either explicitly or implicitly.

As a conclusion, it can be said that urban theories which shelter implications for segregation are not generated universally, but rather in specific frameworks which might or might not be explanatory in other circumstances. Only a combination of these theories can be helpful to understand and manage our contemporary cities. This conclusion verifies Harris's (I96I) view on the necessity of a generalised urban theory.

All in all, it is believed that this evaluation can be guiding for future studies that aim to understand and/or develop the role of urban theories in explaining socio-spatial segregation in the city. A fruitful future work can be directed at the evaluation of planning theories in this regard. The combination of both types of theories can produce a more holistic understanding of how urban segregation is treated within theories regarding the city.

\section{REFERENCES}

1. Anderson, T.R. and Egeland, J. (1961). Spatial Aspects of Social Area Analysis. American Sociological Review, 26(3), 392-398.

2. Batty, M. (2007). Complexity in City Systems: Understanding, Evolution, 
and Design (No. 117). Complexity in City Systems: Understanding, Evolution, and Design (Vol. 44). London: Centre for Advanced Spatial Analysis (UCL). Retrieved from http://eprints.ucl.ac.uk/archive/00003473/

3. Batty, M., and Longley, P. (1994). The Shape of Cities: Geometry, Morphology, Complexity and Form. In Fractal Cities: A Geometry of Form and Function (pp. 7-57). San Diego, CA, and London: Academic Press.

4. Berry, B. (1964). Cities as Systems within Systems of Cities. Papers in Regional Science, 13(1), 146-163.

5. Berry, B. J. L., and Rees, P. H. (1969). The Factorial Ecology of Calcutta. American Journal of Sociology, 74(5), 445-491.

6. Boal, F. W. (1987). Segregation. In, Ceri Peach (Ed.), Social Geography, New York: Progress and Prospect, 124-152.

7. Brand, R. (2009a). Urban Artifacts and Social Practices in a Contested City. Journal of Urban Technology, 16(2), 35-60.

8. Brand, R. (2009b). Written and Unwritten Building Conventions in a Contested City: The Case of Belfast. Urban Studies, 46(12), 2669-2689.

9. Calame, J., Charlesworth, E. (2009). Divided Cities: Belfast, Beirut, Jerusalem, Mostar, and Nicosia. Philadelphia: University of Pennsylvania Press.

10. Davis, M. (1990). City of Quartz: Excavating the Future in Los Angeles. London, NY: Verso.

11. Dear, M., and Flusty, S. (1998). Postmodern urbanism. Annals of the Association of American Geographers, 88(1), 50-72.

12. Driedger, L. (2003). Changing boundaries: Sorting space, class, ethnicity and race in Ontario. Canadian Review of Sociology and Anthropologyrevue Canadienne De Sociologie Et D Anthropologie, 40(5), 593-621.

13. Ersoy, M. (2007). Kentsel Planlama Kuramları. İstanbul: İmge Kitabevi.

14. Fainstein, S. S. (2005). Planning Theory and the City. Journal of Planning Education and Research, 25(2), 121-130.

15. Foucault, M. (1995). Discipline \& Punish: The Birth of the Prison. NY: Vintage Books. Retrieved from http://cartome.org/foucault.htm

16. Fregonese, S., and Brand, R. (2009). Polarization as a Socio-Material Phenomenon: A Bibliographical Review. Journal of Urban Technology, 16(2-3), 9-33.

17. Gaffikin, F. and Morrissey, M. (2011). Planning in Divided Cities. UK: Blackwell Publishing.

18. Harris, B. (1961). Some Problems in the Theory of Intra-Urban Location. Operational Research, 9(5), 695-722.

19. Harris, C. D., and Ullman, E. L. (1945). The Nature of Cities. The Annals of the American Academy of Political and Social Science, 242(1), 7.

20. Harvey, D. (1999). The Limits to Capital. London, NY: Verso Books.

21. Jacobs, J. (1996). The Death and Life of Great American Cities. New York: Random House.

22. Keleş, R. (2002). Kentleşme Politikası. İstanbul: İmge Kitabevi Yayınları.

23. Knox, P. and Pinch, S. (2010). Urban Social Geography: An Introduction. NY: Prentice Hall.

24. Lefebvre, H. (1996), Writings on Cities. Oxford: Blackwell Publishers.

25. Mallenkopf, J. H., and Castells, M. (Eds) (1991). Dual City: Restructuring New York. New York: Harcourt.

26. Marcuse, P. (2002). The Partitioned City in Urban History. In, Peter Marcuse and Ronald van Kempen (Eds.), Of States and Cities: The Partitioning of Urban Space (pp. 11-34). Oxford: Oxford University Press.
27. McLoughlin, J. B. (1969). Urban and Regional Planning: A Systems Approach. London: Faber and Faber.

28. Murdie, R., \& Ghosh, S. (2010). Does Spatial Concentration Always Mean a Lack of Integration? Exploring Ethnic Concentration and Integration in Toronto. Journal of Ethnic and Migration Studies, 36(2), 293-311.

29. Newman, O. (1996). Creating defensible space. Environmental management (Vol. 37, pp. 170-85). U.S. Department of Housing and Urban Development Office of Policy Development and Research.

30. Nightingale, C. H. (2012). Segregation: A global History of Divided Cities. Chicago: The University of Chicago Press.

31. Park, R. (1915). The city: Suggestions for the investigation of behavior in the city environment. American Journal of Sociology, 20(5), 577-612.

32. Park, R. (1936). Human Ecology. American Journal of Sociology, 42(1), $1-15$.

33. Peach, C. (1991). Review of "Ethnic Minority Housing: Explanations and Policies." Housing Studies, 6(1), 73-76.

34. Peach, C. (1996a). The Meaning of Segregation. Planning Practice and Research, 11(2), 137-150.

35. Peach, C. (1996b). Good Segregation, Bas Segregation. Planning Perspectives, 11(4), 379-398.

36. Peach, C. (2005). The mosaic versus the melting pot: Canada and the USA. The Scottish Geographical Magazine, 121(1), 3-27.

37. Rees, P. H. (1971). Factorial ecology: an extended definition, survey, and critique of the field. Economic Geography, 47(Jun.), 220-233.

38. Rogers, A. (1967). Theories of Intraurban Spatial Structure: A Dissenting View. Land Economics, 43(1), 108-112.

39. Safier, M. (1997). Managing Division. City, 2 (8), 188-190.

40. Soja, E. W. (1980). The Socio-spatial Dialectic. Annals of the Association of American Geographers, 70(2), 207-225.

41. Soja, E. (1995). Heteropologies: A Remmemberance of Other Cities in the Citadel-LA. In, Watson, S. and Gibson, K. (Eds.) Postmodern Cities \& Spaces (pp. 243-253), UK: Hartnoll Ltd.

42. Timms, D.W.G. (1978). Social Bases to Social Areas. In, D. T. Herbert and R. J. Johnston (Eds.), Social Areas in Cities: Processes, Patterns and Problems, (pp. 35-55), UK: John Wiley \& Sons.

43. Van Kempen, R. (2007). Divided cities in the 21st century: challenging the importance of globalisation. Journal of Housing and the Built Environment, 22(1), 13-31.

44. Van Kempen, R., and Murie, A. (2009). The New Divided City: Changing Patterns in European Cities. Tijdschrift Voor Economische En Sociale Geografie, 100(4), 377-398.

45. Van Kempen, R., and Özüekren, A. S. (1998). Ethnic Segregation in Cities: New Forms and Explanations in a Dynamic World. Urban Studies, 35(10), 1631-1656.

46. Webber, M. M. et al. (1964). Explorations into Urban Structure. Pennsylvania: University of Pennsylvania Press.

47. Wirth, L. (1945). Human Ecology. American Journal of Sociology, 50(6), $483-488$.

48. Wyly, E. (2010). Theories of Urban System Development. Canadian Journal of Urban Research (Vol. 2005, pp. 1-19). 